0305-750X(95)00065-8

\title{
Small Island Developing States and Their Economic Vulnerabilities
}

\author{
LINO BRIGUGLIO* \\ Foundation for International Studies of the University of Malta
}

\begin{abstract}
Summary. - Many small island developing states (SIDS) face special disadvantages associated with small size, insularity, remoteness and proneness to natural disasters. These factors render the economies of these states very vulnerable to forces outside their control - a condition which sometimes threatens their very economic viability. The GDP or GNP per capita of these states often conceals this reality. In this paper the major vulnerabilities faced by SIDS are discussed and when possible quantified in the form of an index. An attempt is also made to construct a composite index of vulnerability.
\end{abstract}

\section{INTRODUCTION}

Many smail island developing states (SIDS) face special disadvantages associated with small size, insularity, remoteness and proneness to natural disasters. These factors render the economies of these states very vulnerable to forces outside their control - a condition which sometimes threatens their economic viability. The GDP or GNP per capita of these states often conceals this reality.

In this paper the major economic vulnerabilities faced by SIDS are discussed and when possible quantified in the form of an index. An attempt is also made to construct a composite index of vulnerability. The index is not intended as a yardstick of poverty as such, but as a measurement of the lack of economic resilience arising from the relative inability of a small island state to shelter itself from forces outside its control.

The paper is organized as follows. Section 2 gives an account of how the idea of constructing a vulnerability index evolved, and describes the support that the idea has obtained in international fora. Section 3 deals with the special economic disadvantages of SIDS. Section 4 describes the methodology that is utilized for constructing the vulnerability index. An attempt is made to compute this index, using a sample of 114 countries, 21 of which are SIDS. Section 5 concludes the study, with some comments on the weaknesses and benefits of the vulnerability index. This section also puts forward a number of policy recommendations.

\section{HOW THE IDEA EVOLVED}

The idea of constructing a vulnerability index developed in international fora during discussions dealing with the disadvantages faced by island developing countries.

Within the United Nations, the issue of the special problems faced by island developing countries was first specifically raised during UNCTAD III in 1972, where the focus of attention was the disadvantages associated with insularity and remoteness. Subsequently, other fora within UNCTAD identified additional disadvantages peculiar to island developing countries. By 1988 a wide array of such disadvantages were recognized, as evidenced by a comprehensive document prepared by UNCTAD in preparation for a meeting of a group of experts on Island Developing Countries, held in Malta in May 1988. ${ }^{1}$

The deliberations of the Malta meeting led to a UN resolution recognizing that in addition to the general problems faced by developing countries, island developing countries suffer additional handicaps arising from the interplay of such factors as smallness, remoteness, geographical dispersion, vulnerability to natural disasters and a highly limited internal market. ${ }^{2}$

Up to 1990, however, there was no attempt to present the disadvantages faced by island developing countries in a composite index to serve as a yardstick that could measure the degree of overall vulnerability of these countries.

The construction of such an index was first formally proposed by the Maltese Ambassador to the United Nations in June 26, 1990, during the meeting of Government Experts of Island Developing Countries and Donor Countries and Organisations, held under the auspices of UNCTAD. In his speech, the Maltese Ambassador suggested that a vulner-

\footnotetext{
*Final revision accepted: April 12, 1995
} 
ability index be constructed, stating, inter alia, that such an index

is important because it reiterates that the per capita GDP of Island Developing Countries is not by itself an adequate measurement of the level of development of island developing countries as it does not reflect the structural and institutional weaknesses and the several handicaps facing Island Developing Countries.

The issue was again raised and discussed at some length during the International Conference of Islands and Small States, held in Malta on May 23-25, 1991, under the auspices of the Foundation for International Studies at the University of Malta. In its final statement, the conference resolved "to construct a vulnerability index which could be used to supplement GDP per capita index for the purpose of accounting for the special problems associated with small size" and "to explore ways and means to have the United Nations and other international institutions consider such an index for assessing the need for aid to small countries."

Subsequently UNCTAD engaged the present author to prepare a paper on the construction of a vulnerability index - a paper (Briguglio, 1992) which was one of the main documents discussed during a meeting of a Group of Experts on Island Developing Countries, held in Geneva on July 14-15, 1992.

Finally, the General Assembly, at its 47th session, resolved to convene a global conference on the sustainable development of small island developing states (A/Res/47/189 of March 10 1993). The Programme of Action of the global conference, held in Barbados in April 1994, contained a section (paragraphs 113 and 114 ) recommending that a Vulnerability Index be constructed.

\section{THE SPECIAL DISADVANTAGES OF SIDS}

In this section a brief account of the most important vulnerabilities of SIDS is given. These disadvantages are classified under five headings: small size, remoteness and insularity, disaster proneness, environmental fragility, and other factors.

\section{(a) Small size}

The size of a country can be measured in terms of its population, its land area or its gross national product. Some researchers prefer to use population as an index of size, while others take a composite index of the three variables. ${ }^{3}$ As their name implies, smallness is a characteristic of SIDS, but some of these are extremely small, and, as we shall attempt to show, face as a result severe constraints in this regard.
Small size is economically disadvantageous for a number of reasons, including the following:

\section{(i) Limited natural resource endowments and high import content}

Small size often implies poor natural resource endowment and low interindustry linkages, which result in a relatively high import content in relation to GDP (see Briguglio, 1993, Appendix 4). This makes the economy highly dependent on foreign exchange earnings.

\section{(ii) Limitations on import-substitution possibilities}

The small size of a domestic market severely limits import substitution possibilities (Worrell, 1992, p. 9-10). In many SIDS where import-substitution policies were adopted, the end result tended to be a protected economic environment, with inferior quality products, higher prices and a parallel market in nondomestically produced goods.

\section{(iii) Small domestic market and dependence on export markets}

A small domestic market and the need for a relatively large amount of foreign exchange to pay for the large import bill, gives rise to a relatively high dependence on exports (see Briguglio, 1993, Appendix 5) and therefore on economic conditions in the rest of the world.

\section{(iv) Dependence on a narrow range of products}

In many cases, small size restricts the country's ability to diversify its exports, and this renders the country dependent on a very narrow range of goods and services (see Briguglio, 1993, Appendix 6). This carries with it the disadvantage associated with having too many eggs in one basket, and intensifies the problems associated with dependence on international trade.

\section{(v) Limited ability to influence domestic prices}

SIDS have negligible control on the prices of the products they export and import. All developing countries are to an extent price-takers, but SIDS tend to be price-takers to a much higher degree due to the relatively small volume of trade in relation to the world markets in products they import and export.

\section{(vi) Limited ability to exploit economies of scale}

Small size renders it difficult for SIDS to exploit the advantages of economies of scale, mostly due to indivisibilities and limited scope for specialization. In turn this gives rise to, among other things, high per unit costs of production, high costs of infrastructural construction and utilization per capita, high per unit costs of training specialized manpower, and a high degree of dependence on imported technologies, since small size inhibits the development of endogenous technology. 
(vii) Limitations on domestic competition

Domestic competition tends to be curtailed in small economies because small size does not support a large number of firms producing a similar product. This generates a tendency toward oligopolistic and monopolistic organization.

\section{(viii) Problems of public administration 4}

Small size creates problems associated with public administration, the most important of which is probably a small manpower resource base from which to draw experienced and efficient administrators. Very often specialists can only be trained overseas in larger countries, without a guarantee that their services will be needed on their return. For this reason, many specialists originating from SIDS decide to emigrate to larger countries where their services are better utilized and where remuneration for their services is better. One outcome of this is that SIDS have to rely on larger states, generally the ex-colonizing country, for certain specialized aspects of public administration.

A related problem is that many government functions tend to be very expensive per capita when the population is small, because certain expenses are not divisible in proportion to the number of users. For example, overseas diplomatic missions of small islands states are often undermanned, and many such states are represented by roving ambassadors.

Another public administration problem in SIDS is that people know each other well, and are often related to each other. This tends to work against impartiality and efficiency in the civil service and against a meritbased recruitment and promotions policy.

\section{(b) Insularity and remoteness}

All islands are by definition insular, but not all islands are situated in remote areas. Insularity and remoteness give rise to similar problems associated with transport and communication, and these two factors are considered together here.

\section{(i) High per-unit transport}

It is to be expected that transport costs associated with the international trade of SIDS tend to be relatively higher per unit of export than in other countries. The main reason for this is that islands are separated by sea and are therefore constrained to use air and sea transport only for their imports and exports. Land transport is of course out of the question, and this reduces the options available for the movement of goods and of people.

Apart from this, a small economy tends to require relatively small and fragmented cargoes, leading to high per-unit costs. Moreover, the small size of SIDS often excludes them from the major sea and air transport routes, which gives rise to delays and constrains the ability of these states to exploit the advantages of modern and technologically advanced means of transport.

\section{(ii) Uncertainties of supply}

Apart from high per-unit cost of transport, insularity and remoteness from the main commercial centers may also give rise to additional problems such as time delays and unreliability in transport services. These create uncertainties in the provision of industrial supplies. These disadvantages are more intense for islands that are archipelagic and dispersed over a wide area.

\section{(iii) Large stocks}

An additional problem is that when transport is not frequent and/or regular, enterprises on islands find it difficult to meet sudden changes in demand, unless they keep large stocks. This implies additional costs of production, associated with tied-up capital, rent for warehousing and wages of storekeepers.

\section{(c) Proneness to natural disasters}

Many islands experience natural disasters caused by cyclones (hurricanes or typhoons), earthquakes, landslides and volcanic eruptions. Although natural disasters also occur in non-island countries, the impact of a natural disaster on an island economy where disasters occur is expected to be relatively larger in terms of damage per unit of area and costs per capita, due to the small size of the country.

In some instances natural disasters threaten the very survival of some small islands. Some of the effects of natural disasters on small economies include the devastation of the agricultural sector, the wiping out of entire village settlements, the disruption of a high proportion of communication services and injury or death of a relatively high percentage of inhabitants.

\section{(d) Environmental factors}

As is well known, national statistics do not normally take into consideration environmental dcgradation and resource depletion. In other words, GNP statistics may give a picture of growth and development, whereas in reality a country might be undergoing a process of long-term unsustainability. Environmental problems are likely to particularly intense in SIDS.

\section{(i) Pressures arising from economic development}

The pressure on the environment arising from the process of economic development in SIDS tends to be much higher than in other countries. In many islands, increased demand for residential housing and indus- 
trial production has given rise to a fast depletion of agricultural land. Small islands also experience intense use of the coastal zone for tourism and marinerelated activities. They also tend to generate a relatively large amount of waste.

These problems are, of course, also faced by countries undergoing a process of economic development, but their effect on SIDS is likely to be much stronger due to the small size of these countries.

The process of economic development also brings with it an increased demand for resources, some of which are nonrenewable. Some SIDS have experienced depletion or near depletion of such natural resources. This happened, for example, in the case of Fiji (gold), Vanuatu (manganese), Haiti (bauxite), Nauru (phosphate) and Trinidad and Tobago (oil).

\section{(ii) Environmental characteristics of SIDS}

Apart from the pressures of economic development, SIDS also face problems associated with their geographical and natural characteristics.

They tend to have unique and very fragile ecosystems. The uniqueness, which is an outcome of the insularity of SIDS, renders such islands important contributors to global diversity. The fragility is the result of the low level of resistance of SIDS to outside influences, which endangers bird and other endemic species of flora and fauna.

A major environmental problem associated with islands is global warming and rising sea level. Many SIDS, especially the low-lying coral atoll ones, are faced with the prospect of proportionately large land losses as a result of these changes.

Another problem in this regard relates to erosion. SIDS have a relatively large coastline in relation to the land-mass. Thus a relatively large proportion of land in such islands is exposed to sea-waves and winds, giving rise to a relatively high degree of land and soil erosion.

\section{(e) Other characteristics of SIDS}

Other important characteristics of SIDS include dependence on foreign sources of finance and demographic changes.

\section{(i) Dependence on foreign sources of finance}

Some islands have a very high degree of dependence on foreign sources of finance including remittances from emigrants ${ }^{5}$ and development assistance ${ }^{6}$ from donor countries. This reality is especially present in the SIDS in the Pacific region (Bertram, 1993 and Connell, 1988, pp. 27-28). These inflows from abroad have permitted many SIDS to attain high standards of living and to offset trade deficits.

\section{(ii) Demographic factors}

Demographic changes in small islands are sometimes very pronounced due to emigration from the country, or in the case of multi-island states, emigration from one island to another caused by the attraction of urban centers in terms of jobs and education.

These movements sometimes give rise to brain and skill drains and to social upheavals. This happens also in islands which are economically successful, due to limited opportunities for specialization.

\section{CONSTRUCTING A VULNERABILITY INDEX}

In this section an attempt is made to construct an index of economic vulnerability. We have included as many countries as possible, and not just small island states, for the sake of comparison.?

Economic variables are chosen, since the index attempts to measure economic vulnerability. They do not include GDP (or GNP) per capita and other variables which have a causal relation to it, since the issue we wish to investigate here is not related to poverty or underdevelopment, but to vulnerability, fragility and lack of resilience in the face of outside forces. In other words, we are implicitly arguing that a country could be economically vulnerable, independent of its stage of development.

As stated, the index to be constructed in this study includes economic indicators only. It therefore leaves out environmental ones. Apart from the fact that this study focuses on economic vulnerabilities, there is the added reason that there are serious difficulties in obtaining environmental data which could be meaningfully indexed and ranked for international comparative purposes. ${ }^{8}$ The noninclusion of environmental indicators may be considered a major deficiency, because this leaves out an important source of vulnerability of small islands. It should be stressed here that the absence of environmental indicators is not an admission that environmental fragility is not important - on the contrary, the present author believes that this is an important consideration as far as sustainable development of SIDS is concerned.

\section{(a) The basic criteria}

The basic criteria that were adopted to construct the vulnerability index were:

Simplicity: The index should not be too complicated to construct. This necessitates that the data must be relatively easy to obtain and to process. Preferably they should be collected as a matter of routine in line with the information required for the economic management of a country.

Ease of comprehension: This requires that the over- 
Table 1. Indices of trade dependence

\begin{tabular}{lccc}
\hline Averages for different categories of countries* & $\begin{array}{c}\text { Exports/ } \\
\text { GDP\% }\end{array}$ & $\begin{array}{c}\text { Imports/ } \\
\text { GDP\% }\end{array}$ & $\begin{array}{c}\text { Imp + Exp/ } \\
\text { GDP\% }\end{array}$ \\
\hline All countries & 36.73 & 40.97 & 38.85 \\
Island developing countries & 57.31 & 66.11 & 61.69 \\
SIDS & 60.41 & 70.90 & 65.65 \\
Non-island developing countries & 29.15 & 32.86 & 31.00 \\
Developing countries & 38.02 & 43.44 & 0.68 \\
Developed countries & 31.34 & 31.02 & 31.18 \\
\hline
\end{tabular}

*More detailed data on the export and import ratios appear in Appendix C.

Source: IMF, 1991.

all composite index must have an intuitive meaning, that it produces plausible results and that it summarizes the many facets of the individual variables that it purports to represent.

Suitability for international comparison: The index should lend itself to international comparisons. An index of the type we are presenting in this paper would, of course, be useless if it could not be used for this purpose. Hence it must be based on variables which are measured in a homogenous manner internationally.

As we shall show, the vulnerability index that is presented in this paper satisfies, albeit somewhat imperfectly, these three criteria.

\section{(b) The variables}

Three variables which appear to be obvious candidates for inclusion in the vulnerability index are: exposure to foreign economic conditions, insularity and remoteness, and proneness to natural disasters. It is hypothesized that the higher the incidence of these three variables in a given country, the higher the degree of vulnerability in the same country, everything else, including GDP per capita, remaining constant.

\section{(i) Exposure to foreign economic conditions}

The degree of exposure to foreign economic conditions is related to economic vulnerability because the higher the degree of such exposure the more development within the country becomes determined by foreign economic conditions, thereby decreasing the country's capacity to control its own destiny.

Various variables may capture this exposure, including:

- the degree to which an economy depends on foreign trade (exports and imports);

- the degree to which an economy depends on a narrow range of exports;

- the degrec to which an economy depends on imported technologies and imported expertise;

- the degree to which an economy is a price-taker.

We shall refer to these variables as indices of expo- sure to foreign economic conditions. For the purpose of the index we have taken the first variable, measured as the ratio of exports and imports to GDP, as an indicator of economic exposure. The reason for this is that data on the second variable are only available for a limited number of countries, and its inclusion would have severely reduced the number of countries in the index. In addition, it is not possible to measure the third and fourth variables. In all probability however, these variables are closely correlated with the first.

Table 1 gives a summary of the overall trend of SIDS' dependence on exports and imports. More detailed data appear in Appendix $C$.

Table 1 shows that the highest ratios of exports and imports pertain to SIDS whereas developed countries have the lowest ratios.

As already argued, the index of economic exposure is not intended to measure poverty or underdevelopment. As a matter of fact, correlation of this index with GDP per capita was not found to be statistically significant. In other words, countries with a high GDP per capita, as well as those with a low GDP per capita, could have a high index of exposure to what happens in the rest of the world. ${ }^{10}$

\section{(ii) Remoteness and insularity}

The disadvantages associated with remoteness and insularity have been discussed in section 3 . As stated, not all islands are remote, but remoteness renders the problems of insularity more pronounced. Remoteness and insularity are associated with vulnerability because, among other things, they introduce uncertainties, delays and cost indivisibilities in foreign trade.

The problem with remoteness and insularity is that these variables cannot be measured directly in a meaningful way. For example, it may be suggested that remoteness can be measured by taking the number of kilometers from a main commercial center, the nearest island or the nearest continent. An isolation index of this type has been compiled by Dhal (1991, p. 495).

This index might, however, be misleading for measuring remoteness for economic purposes, because the nearest island or continent, or the nearest main commercial center may not be the ones with which the 
Table 2. Transport and freight cost as a percentage of exports

\begin{tabular}{lc}
\hline Average for country categories* & Ratio (\%) \\
\hline All countries & 18.73 \\
Island developing countries & 35.99 \\
SIDS & 43.24 \\
Non-island developing countries & 15.71 \\
Developing countries & 23.75 \\
Developed countries & 4.66 \\
\hline
\end{tabular}

*More detailed data appear in Appendix D.

Source: UNCTAD (1991), Table S.1.

country in question has its most important trade relations. Let us take the case of Malta by way of example. It is not distant from the continent, since Sicily is less than 100 kilometers north. Yet, air transport to London, which is thousands of kilometers away is more frequent and more consistent than it is to Sicily. Moreover, Maltese trade with the United Kingdom and Germany was almost twice that with nearby Italy during the past few years.

In the case of certain islands, a relatively large proportion of international trade is directed to and from their excolonizing powers, even though other centers of commercial activity could be more proximate. In other words measuring remoteness by taking distance in kilometers may convey the wrong sort of information regarding insularity and remoteness, for economic purposes.

We have identified two variables which may reflect the effects of remoteness. These are the ratios of FOB/CIF factors and the other is the ratio of transport and freight costs to exports proceeds. We consider the second more meaningful, and we utilize it in our vulnerability index. Transport and freight ratios are given in Appendix D.

As was the case with the economic exposure variables, the correlation coefficient between relative transport costs and GDP per capita indicates that GDP per capita does not capture the effect of remoteness. ${ }^{11}$

Table 2, which summarizes the data given in Appendix D, shows that SIDS tend to have a higher ratio of expenditure on transport than nonisland countries.

It should be stated, however, that this index needs to be refined considerably to improve its direct relationship with insularity and remoteness, since as it stands, it may reflect factors not necessarily connected with this variable. This point will be briefly discussed again in the concluding section.

\section{(iii) Disaster proneness}

Disaster proneness is associated with economic vulnerability because, among other things, disasters create additional costs and divert resources away from directly productive activities. In small islands, they may disrupt the whole economy.
Table 3. Index of disaster damage as a percentage of GNP

\begin{tabular}{lc}
\hline Average for country categories* & Ratio (\%) \\
\hline All countries with disaster incidence & 28.10 \\
Island developing countries & 51.72 \\
SIDS & 66.52 \\
Non-island developing countries & 20.58 \\
Developing countries & 30.35 \\
Developed countries & 5.10 \\
\hline
\end{tabular}

*More detailed data appear in Appendix F.

Source: UNDRO (1990).

The data for constructing the index of disaster proneness were derived from a 1990 report published by UNDRO which contains a wealth of information in this regard. Disaster damage is calculated as money damage in relation to the GDP of the country concerned. Nonsignificant disasters were excluded, a significant disaster being defined as one which has an impact of at least $1 \%$ of GDP. The period covered by the report is 1970-89 and the disasters covered included droughts, floods, earthquakes, hurricanes, cyclones, storms, typhoons, fire, volcanic eruptions, famine, landslide, accident, power shortage, epidemic and civil strife.

The UNDRO report presents a total index, which gives the estimated damage over a period of 20 years and an average index, which presents data on the damage per disaster. We have taken the total index, since this covers a sufficiently long period to merit the term "proneness."

It is admitted that the choice of a 20-year period is subjective, but so would other choices. We thought it desirable to take a long-run view of disaster proneness. An alternative procedure is to assign declining weights to disaster damage of previous years according to the distance from the current year.

We refined the index somewhat, making it more directly related to natural disaster proneness, by excluding disasters of a political nature. For this reason we excluded damage caused by civil strife.

We tested the correlation of this index with GDP per capita, and again found no statistically significant correlation between the two variables. ${ }^{12}$

Table 3, which summarizes the more detailed data of Appendix C, shows that, according to this index, SIDS tend to be more disaster prone than other countries.

\section{(iv) Other variables}

There are variables other than size, remoteness and disaster proneness that may be associated with vulnerability. Three such variables are environmental fragility, dependence on foreign sources of finance and demographic changes. We decided, however, not to include these three variables on the following grounds: 
Non-measurability: This applies to environmental fragility. Although some environment indices exist (see for example Dhal 1991), the data they convey are not suitable for the purpose of our index, as was explained above.

Relation with GNP per capita: This applies to indices related to dependence on international financial transfers (remittances and international aid) and to emigration. These tend to be related to the economic performance of the country concerned. These were left out because, as stated above, the object of the vulnerability index is not to measure economic performance, but economic fragility in the face of external forces.

\section{(c) Standardizing the variables}

The standardization procedure is required to render the index insensitive to the scale of measurement used, since the variables which compose the index are measured in different units. ${ }^{13}$

The standardization method which is used in this study is based on the following formula:

$$
V i j=\frac{(X i j-\operatorname{Min} X i)}{(\operatorname{Max} X i-\operatorname{Min} X i)} \quad i=1,2,3 ; j=1,2, \ldots, 114 .
$$

where:

$V i j$ stands for the degree of vulnerability arising from the $i$ th variable for country $j$.

$X i j$ stands for the value of the $i$ th variable included in the vulnerability index, for country $j$.

$\operatorname{Max} X i$ and Min $X i$ stand for the maximum and minimum value of the $i$ th variable for all countries in the index.

If a given country's vulnerability variable takes a value of $X i j$ equal to the minimum value of that same variable, the value for $V i j$ would be zero, and this would correspond to minimum vulnerability arising from that same variable.

On the other hand, the greater the gap between the reading of a particular country's vulnerability variable and the minimum value of that same variable, the higher will be the value of $V i j$, so that the country with the maximum value would have a vulnerability score of unity with respect to that variable.

In this manner, the index would take a value of between zero and one.

\section{(i) Weighting the variables for the composite index}

A composite index, as its name implies, is some sort of average of a number of subindices. In our case, we have three subindices which represent different dimensions of vulnerability and which are combined together to yield a single valued indicator.

The simplest method of combining the effect of the subindices is taking a simple average. This would be an equally weighted index. Such an approach has been used in constructing the Physical Quality of Life Index (Morris, 1979) and the UNDP Human Development Index (UNDP, 1991).

An alternative is to use different weights for each variable, on the assumption that the variables each have a different impact on vulnerability. Unfortunately, in the case of our index, there is no way in which such weights can be established on a priori or statistical grounds. The best one can do in this case is to assume different weights and compare the results.

In our case, the subindices are uncorrelated, and therefore significantly different weights are likely to produce different results.

We experimented with two sets of weights. The first is an equally weighted index. The second assigns the following weights to the subindices: $50 \%$ to economic exposure, $40 \%$ to the transport index and $10 \%$ to the disaster-proneness index.

The magnitudes of both sets of weights are essentially arbitrary, but there is the following reason for the ranking in the second set. It could be argued that economic exposure is the most important factor that renders a country economically vulnerable to forces outside its control, since this variable is related to the extent to which the country's economic performance is determined by conditions in the rest of the world. The index of transport cost, reflecting insularity and remoteness, is also related to economic vulnerability, in that, among other things, it allows for an element of uncertainty in foreign trade, but it can be argued that this variable is not as important as economic exposure. Finally while disaster proneness should be considered in an index of economic fragility, it could be argued that this is not an intrinsic economic constraint and it should not therefore be given as much weight as economic exposure and insularity/remoteness.

The equally weighted index produced similar, though not identical results, in that in general SIDS tended to register high vulnerability scores. The main difference was that countries which were disaster prone registered higher scores in the equally weighted index. ${ }^{14}$ The results to be reported below will focus on the index with the second set of weights, based on the arguments just put forward.

It is pertinent to state here that alternative weighting schemes would not solve the problem of subjective choice in this regard.

\section{(d) The vulnerability index}

The ranking of 114 countries according to a vulnerability index using varying weights is given in Appendix A, which lists the countries in alphabetical order and in vulnerability rank order. The scores are summarized in Table 4. This table also gives a sum- 
Table 4. Vulnerability Index for different groups of countries

\begin{tabular}{lccc}
\hline $\begin{array}{l}\text { Averages for } \\
\text { country categories }\end{array}$ & $\begin{array}{c}\text { Number of } \\
\text { countries* }\end{array}$ & \multicolumn{2}{c}{$\begin{array}{c}\text { Vulnerability } \\
\text { Index } \dagger\end{array}$} \\
\hline Index \\
\hline All countries & 114 & .447 & .429 \\
Island developing countries & 29 & .598 & .584 \\
SIDS & 21 & .635 & .624 \\
Non-island developing countries & 63 & .418 & .411 \\
All developing countries & 92 & .475 & .465 \\
Developed countries & 22 & .328 & .278 \\
\hline
\end{tabular}

*The countries included in each category are listed in Appendix $\mathrm{H}$.

$†$ These scores pertain to the scores given in Appendix A, where the sub-indices were assigned varying weights. $\ddagger$ These scores pertain to an index with equally weighted sub-indices.

mary of scores of an index which assigns equal weights to the three subindices. As stated, the general tendency that SIDS have higher vulnerability score is apparent in both indices.

The results shown in Appendix A and Table 4 confirm the assumption that SIDS tend to be more vulnerable than other groupings of countries. In general SIDS registered higher vulnerability scores than developing countries.

As stated elsewhere in this study, the composite index is a form of average, which hides the effect of the individual subindices. Although separate subindices do not have the appeal of a single composite index giving a single-valued ranking, there is something to be said in favor of presenting the subindices separately.

One reason is that they individually convey useful information. Another reason is that a composite index, as Hicks and Streeten (1979) argue, implies some form of tradeoff between the variables composing the index, which have to be viewed together. Averaging would conceal, for example, situations where the effect of one variable cancels out the effect of another. For these reasons we are also presenting the subindices in Appendix F.

Appendix F shows that SIDS, especially the small ones, tend to be vulnerable as a result of the three variables, although there are a number of exceptions.

\section{(e) Vulnerability and economic performance}

As stated above, the types of vulnerabilities represented in the index presented in Appendix A are not related to the degree of economic performance. This is confirmed in Table 5 which gives averages of GDP per capita and of the Human Development Index (for detailed data see Briguglio, 1993, Appendices 7 and 9) of different country groups and compares them to the Vulnerability Index. It can be seen that SIDS do not fare badly in terms of GDP per capita, and in terms of
Table 5. Vulnerability Index and indices of material welfare for different groups of countries

\begin{tabular}{lccc}
\hline $\begin{array}{l}\text { Averages for } \\
\text { country categories }\end{array}$ & $\begin{array}{c}\text { Vulnerability } \\
\text { Index }\end{array}$ & $\begin{array}{c}\text { GDP per } \\
\text { capita US\$ }\end{array}$ & $\begin{array}{c}\text { Human } \\
\text { Dev. Index }\end{array}$ \\
\hline All countries & .447 & 4468 & .588 \\
Island dev. countries & .598 & 3165 & .670 \\
SIDS & .635 & 3384 & .698 \\
Non-island developing & & & \\
$\quad$ countries & .418 & 2890 & .565 \\
All developing countries & .475 & 2191 & .535 \\
Developed countries & .328 & 16740 & .962 \\
\hline
\end{tabular}

Source: GDP per capita taken from UNCTAD (1991),

Table 6.1 and Human Development Index from UNDP (1991).

the Human Development Index. As a matter of fact, their scores are higher, on average, than those of developing countries in general. On average, however, these countries are characterized by high vulnerability scores.

The question may arise here is to whether the data in Table 5 suggest that the economic fragilities of SIDS are actually the reason for their relatively high GDP per capita and Human Development Index. The fact that many SIDS have done relatively well in terms these indices, has prompted some observers to argue that being small and insular is not a disadvantage after all.

This line of argument may, of course, contain an element of truth, in that smallness has its advantages, including a high degree of flexibility in the face of changing circumstances. The handicaps and fragilities described above, however, are a reality for many SIDS, and the success stories of some of them were probably achieved in spite of and not because of their small size and insularity. Unlike larger states, small ones can never take their viability for granted, and they are perpetually in a "sink or swim" situation.

One reason why many SIDS register relatively high GNP per capita scores could be their strategic importance. Many SIDS are situated in the sphere of influence of relatively large power: the United Kingdom and the United States in the Caribbean region; the European Union (EU) in the Mediterranean region; and Australia, New Zealand, Japan and France in the Pacific area. The interest of these powers in SIDS has given rise to what may be called "artificial" props to the economy of the islands, in terms of, among other things relatively large amounts of transfers and free technical assistance and preferential access to the markets of developed countries in industrial and agricultural products.

Because of their intrinsic economic vulnerabilities, many SIDS may not have survived as independent states in the absence of these "artificial" props. Furthermore, it could be argued that the relatively 
large financial transfers to SIDS may have pushed up their GDP per capita to levels higher than what one would expect from countries continually facing the constraints associated with small size and limited resources.

The relatively high growth rates which many SIDS experienced during the 1980 s may also give a misleading picture of the strength of the economies of these countries. In many instances, the growth pattern of such countries has been unstable and erratic (as was the case in many Caribbean Islands; see World Bank, 1982 , p. 6) and dependent on preferential access to markets in developed countries.

\section{(f) Vulnerability adjusted development index}

An interesting consideration in this regard is the comparison of the vulnerability ranking and the GDP per capita ranking. For this purpose we have constructed a simple index which, for ease of reference and for lack of a better name, we call the "Vulnerability Adjusted Development Index"(VADI).

This index consists of a simple average of the GDP per capita and the vulnerability index. The results are given in Appendix F, where it can be seen that in the case of most SIDS the vulnerability index "weighs down" the GDP per capita index.

For example, Antigua and Barbuda have a very high vulnerability score (ranked number one in terms of vulnerability among all countries). At the same time, this country has a relatively high GDP per capita score (ranked 78, where rank one indicates the poorest country among the 114 included in the table). As a result the VADI score of Antigua and Barbuda has a lower rank than its GDP per capita index. Countries such as Antigua and Barbuda, which have a GDP per capita rank higher than their VADI rank are termed "countries with an overrated GDP per capita" for ease of reference.

A list of such countries also appears in Appendix F. This appendix gives the magnitude of disparity between the GDP per capita rank and the VADI rank.

The results indicate that many small states, most of which are also islands, have an economy which appears stronger in terms of GDP per capita, than in terms of a Vulnerability Adjusted Development Index.

\section{(g) Suggestions for improvement}

Composite indices are notorious for the amount of discussion they provoke, principally because of the subjectivity in their computation. Normally, the criteria as to which variables are to be included and weighted are chosen by the compiler. In general, one finds that there are no hard and fast rules for rejecting or accepting the results. Indices of this type are also sometimes criticized because they contain errors of measurement. (i) Subjectivity

The Vulnerability Index proposed in this paper can, no doubt, be criticized on the grounds of subjectivity. Care, however, has been taken to base the choice of variables on plausible assumptions as to what renders an economy vulnerable to forces outside its control, and to use suitable methods of measurement and weighting, guided by the simplicity and comprehensibility criteria outlined at the beginning of section 4 .

\section{(ii) Errors in measurement}

Measurement errors are generally found in indices which attempt to construct numerical values for variables which are essentially qualitative.

For example, in the case of the economic exposure index, it is quite possible for a country to be very economically exposed, yet not developed enough or not competitive enough to foster foreign trade. Such errors in measurement may have been the cause of a number of unexpected, and perhaps implausible, rankings in the Vulnerability Index. Clearly, this aspect of the index needs to be investigated in more depth.

Moreover, certain data are not easy to procure. The most difficult task in this regard would seem to be that of obtaining regular updated data on disaster proneness. The index produced by UNDRO is an important step in this direction, but it has to be produced on a yearly basis.

There is also the need for further study to improve the remoteness index by means of data which measure this variable, keeping other things constant. The index chosen in the present study has the merit that it can be very easily obtained from balance-of-payments statistics. But it may capture factors which are not directly related to remoteness, such as monopolistic practices in the domestic carrier-companies and other market distortions.

\section{CONCLUSION}

In this study we have described the most important factors which render a small island developing state relatively weaker than other countries in the face of factors outside its control, and we have proposed a method for constructing an index to measure economic vulnerability. The index presented in this study has a number of weaknesses, which have already been highlighted, and which include three basic ones, namely the subjective criteria on which it is constructed, the errors in measurement, and the lack of consideration for environmental vulnerabilities.

In spite of its shortcomings, there are a number of benefits that may be derived from the index, especially if refined in the manner indicated above, and computed on an ongoing basis with updated data. These benefits include the following:

(a) the index can attract attention toward the issue of vulnerability of certain economies, in particular 
those of SIDS; and

(b) it presents a single-value measure of vulnerability based on meaningful criteria which can be considered by donor countries and organizations when making decisions regarding the allocation of financial aid and technical assistance.

This study has also shown that vulnerability takes many forms and that SIDS tend to have high scores in this regard, indicating that these countries may be very fragile in the face of forces outside their control.

It has also been shown that in many instances, SIDS do not have a relatively low GDP per capita, conveying the impression of a relatively strong economy, even when, in reality, their economies are extremely delicate. They are exposed to foreign economic conditions and to natural disasters, and have additional problems associated with insularity and remoteness. In other instances, SIDS are very poor and very vulnerable at the same time, a state of affairs which deserves immediate attention from the international community.

It must be emphasized that the high vulnerability scores of SIDS produced in the vulnerability index does not suggest that SIDS should be complacent and should not themselves attempt to mitigate the effects of their vulnerabilities. The report of the General Secretary of United Nations, relating to Island
Developing Countries (United Nations 1992, pp. 19-23) lists a number of policy options available to SIDS in this regard.

These include: improved flexibility to enhance the countries' ability to withstand external shocks; improved ability to compete, through niche-filling export strategy, flexible specialization, enhanced entrepreneurship and economic deregulation (on this question see also Cole, 1993); institutional changes for capacity building (in this regard see Ashe, Singh and Paul, 1993); and regional technical cooperation to reduce certain per unit costs which tend to be high in a small state.

Additional recommendations, related to environmental vulnerability, are included in UNCED's AGENDA 21 (1992, Chapter 17G). These include the development of management techniques suitable to the special characteristics of small islands; the undertaking of appropriate institutional reforms essential to effective implementation of sustainable development; and the promotion of environmentally sound technology.

Although, as stated, SIDS should take action to help themselves, the fact remains that these countries tend to have limited options to cope effectively with their intrinsic economic and environmental vulnerabilities. The cooperation of the international community is therefore called for in this regard.

\section{NOTES}

\section{See UNCTAD (1988).}

2. See "Resolutions adopted on the reports of the second committee" Meeting 83, Report A/43/915/Add.2 dated December 20, 1988.

3. See Downes (1988), Jalan (1982), and Briguglio (1993, Appendix 1).

4. These arguments are derived from on Jacobs (1989) and Connell (1988, pp. 4-6).

5. Figures pertaining to these variables are published in UNCTAD (1991) Table 5.1 and 5.14. These figures would seem to suggest that SIDS are more dependent on remittances than nonisland developing countries, having on average received $11 \%$ of their GNP in remittances in 1990 , compared to $5 \%$ of GNP for nonisland developing countries. On this issue see Bertram (1993). On the other hand, debt statistics would seem to indicate that SIDS tend to have a relatively lower debt burden than other developing countries.

6. Overseas Development Assistance per capita of population to SIDS in 1989 was about six times as large as the average for all developing countries in general (United Nations, 1992, Annex, Table 5).

7. The index does not include all island developing states and territories, since data were not available for some of them, including Cuba, Solomon Islands, Såo Tome and
Principe, Western Samoa, the Federated States of Micronesia, Cook Islands, Marshall Islands, Nauru, Niue and Tuvalu.

8. The measurement of environmental fragility is not an easy task, especially if this measurement is to be utilized for international comparisons across island and nonisland states. A very useful attempt in this regard was carried out by $A . L$. Dhal, whose work was published as an Island Directory (Dhal, 1991). Dhal produces a number of indices, including an index of the richness of the ecosystem of islands, an index of species richness and an index of human impact threatening natural areas and endemic species. He uses these subindices to construct two composite indices, namely the Index of Terrestrial Conservation Importance and the Index of Marine Conservation Importance, both of which assign higher ratings to islands with greater ecological complexities and species diversity and with larger numbers of endangered and threatened species. Using these indices, Dhal produces a table (page 557), which lists the most important islands at risk because of their high conservation importance and the high human impact index. The principal operational uses of the Dhal indices are related to the ranking of islands in terms of priorities for terrestrial and marine conservation action. Dhal's indices are extremely interesting and very comprehensive but they could not be utilized for the purpose of the index constructed in this study. The main reason for this is that Dhal's indices only cover islands, whereas the index to be constructed in this study covers all types of countries, since the object of the exercise is to show that small islands have a higher degree of vulnerability than other countries. 
9. UNCTAD's Handbook of International Trade and Development Statistics (Table 4.5) presents an index measuring export concentration by means of a formula which takes a value of between zero and one, where one is maximum concentration of exports. According to the data in the 1991 issue of the handbook, SIDS in general registered very high concentration scores averaging .845 . Nonisland developing countries had an average score of 767 whereas developed countries on average registered the relatively low score of .424 .

10. The rank correlation coefficient between exports and imports as a percentage of GDP and GDP per capita of the 114 countries used in computing the vulnerability index was found to be .04 .

11. The rank correlation coefficient between GDP per capita and the transport costs ratio was found to be 0.10 .

12. The rank correlation coefficient between GDP per capita and the disaster proneness index was found to be 0.03 .

13. The variables were actually measured in logs to allow for diminishing marginal effects. When measuring the variables in absolute terms, one is implicitly assuming that these vari- ables have a constant marginal effect with regard to vulnerability. An alternative assumption is that the variables have a diminishing marginal impact. In the case of the disaster proneness index, for example, the assumption of diminishing marginal impact would imply that a country twice as prone to natural disasters as another, is less than twice as vulnerable, with respect to this variable. This question cannot be resolved on the basis of objective criteria, but it appears plausible to assume that as economic exposure, remoteness and disaster-proneness increase, the vulnerabilities arising from these variables tend to increase at a diminishing rate. One way of allowing for a diminishing marginal effect of a variable is to measure it in logarithms - the method used in this study. An alternative is to measure it in terms of a formula assigning declining weights to increments of the variable. We have decided to use logs for this purpose, on the grounds that it is relatively easy to transform raw data in this manner.

14. The results of an equally weighted vulnerability index are given in Briguglio (1993). The vulnerability rankings of particular countries differed somewhat from those shown in the present study, but the conclusion that SIDS tend to be more economically vulnerable than other countries also emerged very clearly from the results.

\section{REFERENCES}

Ashe, J. W., N. C. Singh and J. D. Paul, "Institutional arrangements for small-island developing countries within the framework of UNCED's Agenda 21," INSULA, Vol. 2, No. 1 (1993), pp. 7-14.

Bertram, G., "Sustainability, aid and material welfare in small pacific island economies," World Development. Vol. 21 , No. 2 (1993), pp. 247-258.

Briguglio, L., "The economic vulnerabilities of small island developing states," Study commissioned by CARICOM for the Regional Technical Meeting of the Global Conference on the Sustainable Development of Small Island Developing States (Port of Spain, Trinidad and Tobago: July 1993).

Briguglio, L., Preliminary Study on the Construction of an Index for Ranking Countries According to their Economic Vulnerability, UNCTAD/LDC/Misc. 4 (Geneva: UNCTAD, 1992).

Cole, R., "Economic development in the South Pacific: Promoting the private sector," World Development, Vol. 21, No. 2 (1993), pp. 233-245.

Downes, A.S., "On the statistical measurement of smallness: A principal component measure of size," Social and Economic Studies, Vol. 37, No. 3 (1988).

Connell, J., "Sovereignty and survival: Island microstates in the Third World," Monograph No. 3 (Sydney: Department of Geography, University of Sydney, 1988).

Dhal, A. L., Island Directory (Nairobi, Kenya: UNEP, 1991).

Hicks, N. and P. Streeten, "Indicators of development." World Development, Vol. 7 (1970), pp. 567-580.

IMF, International Financial Statistics Yearbook (Washington, DC: IMF, 1991).

Jalan, B., "Classification of economics by size," in B. Jalan (Ed.), Problems and Policies in Small Countries (London: Croom Helm, 1982).

Jacobs, J., "Reflections of a Non-Economist," in J.
Kaminarides, L. Briguglio, and H. Hoogendonk (Eds.), The Economic Development of Small Countries Problems, Policies and Strategies (Amsterdam: Eburon Publishers, 1989).

Morris, D. M., Measuring the Conditions of the World's Poor (London: Overseas Development Council, 1979).

Searwar L., Intrinsic Disabilities of Island Developing Countries UNCTAD/RDP/LDC/31 (Geneva: UNCTAD, 1990).

United Nations, Specific Problems and Needs of Island Developing Countries, General Assembly A/47/414 (New York: UN, 1992).

UNCED, AGENDA 21 (reproduced in an abridged form in The Earth Summit London: Regency Press, 1992).

UNCTAD, Handbook of International Trade and Development Statistics (New York, United Nations, 1991).

UNCTAD, Problems of Island Developing Countries and Proposals for Concrete Action, TD/B/AC.46.2 (Geneva: UNCTAD, 1990).

UNCTAD, Specific Problems of Island Developing Countries, LDC/Misc/17, (Geneva: UNCTAD, 1988).

UNCT AD Secretariat and UNDRO The Incidence of Natural Disasters in Island Developing Countries (TD/B/961) (Geneva: UNCTAD/UNDRO, 1983).

UNDRO, Preliminary Study on the Identification of Disaster-Prone Countries. Based on Economic Impact (Geneva: UNDRO, 1990).

UNDP, Human Development Report (New York: Oxford University Press, 1991).

World Bank, Caribbean Region: Current Economic Situation. Regional Issues and Capital Flows (Washington, DC: World Bank, 1992).

Worrell, D. Economic Policies in Small Open Economies: Prospects for the Caribbean. Economic Paper No. 23 (London: Commonwealth Secretariat, 1992). 
APPENDIX A

VULNERABILITY INDEX (COUNTRY ALPHABETICAL ORDER)

\begin{tabular}{|c|c|c|c|c|c|}
\hline Country & Index & Rank & Country & Index & Rank \\
\hline Afghanistan & 0.364 & 84 & Korea & 0.295 & 98 \\
\hline Algeria & 0.323 & 91 & Kuwait & 0.468 & 47 \\
\hline Antigua \& Barbuda & 0.843 & 1 & Liberia & 0.439 & 58 \\
\hline Argentina & 0.157 & 113 & Libya & 0.376 & 78 \\
\hline Australia & 0.322 & 92 & Madagascar & 0.428 & 62 \\
\hline Austria & 0.362 & 86 & Malawi & 0.534 & 30 \\
\hline Bahamas & 0.633 & 11 & Malaysia & 0.488 & 40 \\
\hline Bahrain & 0.588 & 21 & Maldives & 0.579 & 22 \\
\hline Bangaladesh & 0.423 & 65 & Mali & 0.577 & 23 \\
\hline Barbados & 0.595 & 20 & Malta & 0.605 & 16 \\
\hline Belgium & 0.429 & 60 & Mauritania & 0.558 & 27 \\
\hline Belize & 0.611 & 15 & Mauritius & 0.614 & 14 \\
\hline Benin & 0.485 & 43 & Mexico & 0.254 & 107 \\
\hline Bolivia & 0.450 & 52 & Morocco & 0.388 & 74 \\
\hline Botswana & 0.534 & 29 & Mozambique & 0.389 & 73 \\
\hline Brazil & 0.110 & 114 & Nepal & 0.456 & 51 \\
\hline Cameroon & 0.365 & 82 & Netherlands & 0.449 & 53 \\
\hline Canada & 0.204 & 110 & New Zealand & 0.410 & 68 \\
\hline Cape Verde & 0.498 & 38 & Niger & 0.423 & 64 \\
\hline Chad & 0.686 & 7 & Nigeria & 0.309 & 94 \\
\hline Chile & 0.377 & 77 & Norway & 0.324 & 90 \\
\hline China, Republic & 0.299 & 97 & Oman & 0.416 & 67 \\
\hline Colombia & 0.292 & 100 & Pakistan & 0.394 & 72 \\
\hline Comoros & 0.602 & 17 & Panama & 0.503 & 36 \\
\hline Congo & 0.500 & 37 & Papua New Guinea & 0.487 & 42 \\
\hline Cote d'Ivoire & 0.440 & 56 & Paraguay & 0.458 & 49 \\
\hline Cyprus & 0.568 & 26 & Peru & 0.240 & 109 \\
\hline Denmark & 0.364 & 83 & Philippines & 0.368 & 81 \\
\hline Dominica & 0.600 & 18 & Portugal & 0.443 & 55 \\
\hline Dominican Republic & 0.512 & 34 & Saudi Arabia & 0.445 & 54 \\
\hline Ecuador & 0.349 & 87 & Senegal & 0.521 & 31 \\
\hline El Salvador & 0.432 & 59 & Seychelles & 0.756 & 3 \\
\hline Ethiopia & 0.504 & 35 & Sierra Leone & 0.405 & 70 \\
\hline Fiji & 0.573 & 24 & Singapore & 0.649 & 8 \\
\hline Finland & 0.308 & 95 & Spain & 0.305 & 96 \\
\hline France & 0.319 & 93 & Sri Lanka & 0.468 & 46 \\
\hline Gabon & 0.476 & 44 & St. Kitts and Nevis & 0.733 & 5 \\
\hline Gambia & 0.596 & 19 & St. Lucia & 0.715 & 6 \\
\hline Germany & 0.276 & 103 & St. Vincent & 0.649 & 9 \\
\hline Greece & 0.402 & 71 & Sudan & 0.264 & 105 \\
\hline Grenada & 0.635 & 10 & Surinam & 0.368 & 80 \\
\hline Guatemala & 0.409 & 69 & Swaziland & 0.488 & 41 \\
\hline Guinea Bissau & 0.520 & 32 & Sweden & 0.282 & 101 \\
\hline Guyana & 0.519 & 33 & Switzerland & 0.339 & 88 \\
\hline Haiti & 0.461 & 48 & Syrian Arab Republic & 0.280 & 102 \\
\hline Honduras & 0.428 & 61 & Tanzania & 0.497 & 39 \\
\hline Hungary & 0.372 & 79 & Thailand & 0.458 & 50 \\
\hline Iceland & 0.292 & 99 & Tonga & 0.759 & 2 \\
\hline India & 0.243 & 108 & Trinidad and Tobago & 0.416 & 66 \\
\hline Ireland & 0.428 & 63 & Tunisia & 0.440 & 57 \\
\hline Israel & 0.384 & 75 & United Kingdom & 0.274 & 104 \\
\hline Italy & 0.336 & 89 & United States & 0.159 & 112 \\
\hline Jamaica & 0.631 & 12 & Uruguay & 0.261 & 106 \\
\hline Japan & 0.179 & 111 & Vanuatu & 0.751 & 4 \\
\hline Jordan & 0.572 & 25 & Yemen Arab Republic & 0.540 & 28 \\
\hline Kenya & 0.469 & 45 & Yugoslavia & 0.363 & 85 \\
\hline Kiribati & 0.627 & 13 & Zimbabwe & 0.377 & 76 \\
\hline
\end{tabular}


APPENDIX B

VULNERABILITY INDEX (RANK ORDER)

\begin{tabular}{|c|c|c|c|c|c|}
\hline Country & Score & Rank & Country & Score & Rank \\
\hline Antigua \& Barbuda & 0.843 & 1 & Liberia & 0.439 & 58 \\
\hline Tonga & 0.759 & 2 & El Salvador & 0.432 & 59 \\
\hline Seychelles & 0.756 & 3 & Belgium & 0.429 & 60 \\
\hline Vanuata & 0.751 & 4 & Honduras & 0.428 & 61 \\
\hline St. Kitts and Nevis & 0.733 & 5 & Madagascar & 0.428 & 62 \\
\hline St. Lucia & 0.715 & 6 & Ireland & 0.428 & 63 \\
\hline Chad & 0.686 & 7 & Niger & 0.423 & 64 \\
\hline Singapore & 0.648 & 8 & Bangladesh & 0.423 & 65 \\
\hline St. Vincent & 0.649 & 9 & Trinidad and Tobago & 0.416 & 66 \\
\hline Grenada & 0.635 & 10 & Oman & 0.416 & 67 \\
\hline Baharnas & 0.633 & 11 & New Zealand & 0.410 & 68 \\
\hline Jamaica & 0.631 & 12 & Guatemala & 0.409 & 69 \\
\hline Kiribati & 0.627 & 13 & Sierra Leone & 0.405 & 70 \\
\hline Mauritius & 0.614 & 14 & Greece & 0.402 & 71 \\
\hline Belize & 0.611 & 15 & Pakistan & 0.394 & 72 \\
\hline Malta & 0.605 & 16 & Mozambique & 0.389 & 73 \\
\hline Comoros & 0.602 & 17 & Morocco & 0.388 & 74 \\
\hline Dominica & 0.600 & 18 & Israel & 0.384 & 75 \\
\hline Gambia & 0.596 & 19 & Zimbabwe & 0.377 & 76 \\
\hline Barbados & 0.595 & 20 & Chile & 0.377 & 77 \\
\hline Bahrain & 0.588 & 21 & Libya & 0.376 & 78 \\
\hline Maldives & 0.579 & 22 & Hungary & 0.372 & 79 \\
\hline Mali & 0.577 & 23 & Surinam & 0.368 & 80 \\
\hline Fiji & 0.573 & 24 & Philippines & 0.368 & 81 \\
\hline Jordan & 0.572 & 25 & Cameroon & 0.365 & 82 \\
\hline Cyprus & 0.568 & 26 & Denmark & 0.364 & 83 \\
\hline Mauritania & 0.558 & 27 & Afghanistan & 0.364 & 84 \\
\hline Yemen Arab Republic & 0.540 & 28 & Yugoslavia & 0.363 & 85 \\
\hline Botswana & 0.534 & 29 & Austria & 0.362 & 86 \\
\hline Malawi & 0.534 & 30 & Ecuador & 0.349 & 87 \\
\hline Senegal & 0.521 & 31 & Switzerland & 0.339 & 88 \\
\hline Guinea Bissau & 0.520 & 32 & Italy & 0.336 & 89 \\
\hline Guyana & 0.519 & 33 & Norway & 0.324 & 90 \\
\hline Dominican Republic & 0.512 & 34 & Algeria & 0.323 & 91 \\
\hline Ethiopia & 0.504 & 35 & Australia & 0.322 & 92 \\
\hline Panama & 0.503 & 36 & France & 0.319 & 93 \\
\hline Congo & 0.500 & 37 & Nigeria & 0.309 & 94 \\
\hline Cape Verde & 0.498 & 38 & Finland & 0.308 & 95 \\
\hline Tanzania & 0.497 & 39 & Spain & 0.305 & 96 \\
\hline Malaysia & 0.488 & 40 & China, Republic & 0.299 & 97 \\
\hline Swaziland & 0.488 & 41 & Korea & 0.295 & 98 \\
\hline Papua New Guinea & 0.487 & 42 & Iceland & 0.292 & 99 \\
\hline Benin & 0.485 & 43 & Colombia & 0.292 & 100 \\
\hline Gabon & 0.476 & 44 & Sweden & 0.282 & 101 \\
\hline Kenya & 0.469 & 45 & Syrian Arab Republic & 0.280 & 102 \\
\hline Sri Lanka & 0.468 & 46 & Germany & 0.276 & 103 \\
\hline Kuwait & 0.468 & 47 & United Kingdom & 0.274 & 104 \\
\hline Haiti & 0.461 & 48 & Sudan & 0.264 & 105 \\
\hline Paraguay & 0.458 & 49 & Uruguay & 0.261 & 106 \\
\hline Thailand & 0.458 & 50 & Mexico & 0.254 & 107 \\
\hline Nepal & 0.456 & 51 & India & 0.243 & 108 \\
\hline Bolivia & 0.450 & 52 & Peru & 0.240 & 109 \\
\hline Netherlands & 0.449 & 53 & Canada & 0.204 & 110 \\
\hline Saudi Arabia & 0.445 & 54 & Japan & 0.179 & 111 \\
\hline Portgual & 0.443 & 55 & United States & 0.159 & 112 \\
\hline Cote d'Ivoire & 0.440 & 56 & Argentina & 0.157 & 113 \\
\hline Tunisia & 0.440 & 57 & Brazil & 0.110 & 114 \\
\hline
\end{tabular}


APPENDIX C

EXPORT AND IMPORTS AS A PERCENTAGE OF GDP*

\begin{tabular}{|c|c|c|c|c|c|}
\hline Country & $\%$ & Rank & Country & $\%$ & Rank \\
\hline Afghanistan & 9.00 & 111 & Korea & 35.18 & 51 \\
\hline Algeria & 14.30 & 103 & Kuwait & 46.68 & 34 \\
\hline Antigua \& Barbuda & 115.95 & 2 & Liberia & 38.85 & 42 \\
\hline Argentina & 11.58 & 105 & Libya & 27.70 & 65 \\
\hline Australia & 16.98 & 97 & Madagascar & 17.50 & 95 \\
\hline Austria & 37.63 & 46 & Malawi & 28.00 & 61 \\
\hline Bahamas & 73.60 & 11 & Malaysia & 63.57 & 19 \\
\hline Bahrain & 95.33 & 4 & Maldives & 99.50 & 3 \\
\hline Bangladesh & 13.12 & 104 & Mali & 25.68 & 70 \\
\hline Barbados & 47.50 & 33 & Malta & 83.43 & 8 \\
\hline Belgium & 68.55 & 16 & Mauritania & 52.52 & 24 \\
\hline Belize & 68.95 & 15 & Mauritius & 68.18 & 17 \\
\hline Benin & 32.20 & 56 & Mexico & 15.82 & 101 \\
\hline Bolivia & 15.82 & 100 & Morocco & 24.57 & 79 \\
\hline Botswana & 75.97 & 9 & Mozambique & 9.35 & 109 \\
\hline Brazil & 7.83 & 112 & Nepal & 19.53 & 88 \\
\hline Cameroon & 17.25 & 96 & Netherlands & 51.40 & 27 \\
\hline Canada & 25.58 & 71 & New Zealand & 26.72 & 68 \\
\hline Cape Verde & 30.08 & 61 & Niger & 21.63 & 86 \\
\hline Chad & 41.45 & 39 & Nigeria & 23.37 & 83 \\
\hline Chile & 32.45 & 55 & Norway & 37.78 & 45 \\
\hline China, Republic & 15.00 & 102 & Oman & 39.00 & 41 \\
\hline Colombia & 16.82 & 98 & Pakistan & 19.02 & 93 \\
\hline Comoros & 25.00 & 75 & Panama & 71.72 & 12 \\
\hline Congo & 52.60 & 23 & Papua New Guinea & 46.07 & 35 \\
\hline Cote d'Ivoire & 35.30 & 50 & Paraguay & 28.83 & 62 \\
\hline Cyprus & 51.13 & 29 & Peru & 9.55 & 108 \\
\hline Denmark & 33.15 & 54 & Philippines & 25.00 & 76 \\
\hline Dominica & 51.60 & 26 & Portugal & 38.63 & 43 \\
\hline Dominican Republic & 36.93 & 47 & Saudi Arabia & 41.60 & 38 \\
\hline Ecuador & 24.23 & 81 & Senegal & 32.20 & 57 \\
\hline El Salvador & 21.75 & 85 & Seychelles & 70.28 & 14 \\
\hline Ethiopia & 16.52 & 99 & Sierra Leone & 25.25 & 74 \\
\hline Fiji & 49.15 & 32 & Singapore & 183.45 & 1 \\
\hline Finland & 24.65 & 78 & Spain & 19.29 & 91 \\
\hline France & 22.70 & 84 & Sri Lanka & 31.30 & 60 \\
\hline Gabon & 44.45 & 32 & St. Kitts and Nevis & 90.35 & 6 \\
\hline Gambia & 65.60 & 18 & St. Lucia & 94.05 & 5 \\
\hline Germany & 27.22 & 66 & St. Vincent & 74.50 & 10 \\
\hline Greece & 24.42 & 80 & Sudan & 6.60 & 114 \\
\hline Grenada & 71.50 & 13 & Surinam & 32.20 & 58 \\
\hline Guatemala & 19.33 & 90 & Swaziland & 84.00 & 7 \\
\hline Guinea Bissau & 27.15 & 67 & Sweden & 31.92 & 59 \\
\hline Guyana & 62.25 & 20 & Switzerland & 42.28 & 37 \\
\hline Haiti & 18.75 & 94 & Syrian Arab Republic & 10.90 & 106 \\
\hline Honduras & 24.12 & 82 & Tanzania & 26.48 & 69 \\
\hline Hungary & 36.37 & 48 & Thailand & 34.28 & 53 \\
\hline Iceland & 34.85 & 52 & Tonga & 51.80 & 25 \\
\hline India & 7.40 & 113 & Trinidad and Tobago & 35.62 & 49 \\
\hline Ireland & 58.60 & 21 & Tunisia & 41.25 & 40 \\
\hline Israel & 38.20 & 44 & United Kingdom & 25.52 & 72 \\
\hline Italy & 19.15 & 92 & United States & 9.65 & 107 \\
\hline Jamaica & 51.37 & 28 & Uruguay & 20.02 & 87 \\
\hline Japan & 9.33 & 110 & Vanuatu & 50.15 & 30 \\
\hline Jordan & 53.48 & 22 & Yemen Arab Republic & 19.45 & 89 \\
\hline Kenya & 23.35 & 73 & Yugoslavia & 24.68 & 77 \\
\hline Kiribai & 50.00 & 31 & Zimbabwe & 28.20 & 63 \\
\hline
\end{tabular}

Source: IMF (1991). pp. 148-151.

*The percentages are computed as $(M+X) /(2 \times G) \times 100$, where $M=$ Imports, $X=$ Exports and $G=G D P$. The data pertain to a three-year period (1987-89). 
APPENDIX D TRANSPORT AND FREIGHT COSTS AS A PERCENTAGE OF MERCHANDISE EXPORTS

\begin{tabular}{|c|c|c|c|c|c|}
\hline Country & $\%$ & Rank & Country & $\%$ & Rank \\
\hline Afghanistan & 27.04 & 33 & Korea & 1.75 & 137 \\
\hline Algeria & 7.53 & 97 & Kuwait & 9.39 & 84 \\
\hline Antigua \& Barbuda & 83.24 & 4 & Liberia & 9.23 & 85 \\
\hline Argentina & 1.95 & 135 & Libya & 7.83 & 92 \\
\hline Australia & 7.21 & 98 & Madagascar & 18.98 & 44 \\
\hline Austria & 3.67 & 123 & Malawi & 47.09 & 13 \\
\hline Bahamas & 32.21 & 27 & Malaysia & 6.67 & 101 \\
\hline Bahrain & 10.94 & 77 & Maldives & 8.97 & 86 \\
\hline Bangladesh & 25.47 & 34 & Mali & 57.33 & 10 \\
\hline Barbados & 46.03 & 16 & Malta & 17.59 & 49 \\
\hline Belgium & 2.70 & 128 & Mauritania & 9.77 & 82 \\
\hline Belize & 17.34 & 50 & Mauritius & 12.24 & 70 \\
\hline Benin & 23.81 & 36 & Mexico & 3.79 & 120 \\
\hline Bolivia & 20.82 & 41 & Morocco & 11.47 & 72 \\
\hline Botswana & 4.96 & 110 & Mozambique & 59.52 & 9 \\
\hline Brazil & 2.27 & 131 & Nepal & 21.98 & 38 \\
\hline Cameroon & 16.90 & 53 & Netherlands & 6.11 & 103 \\
\hline Canada & 1.01 & 139 & New Zealand & 13.07 & 65 \\
\hline Cape Verde & 17.86 & 48 & Niger & 11.14 & 76 \\
\hline Chad & 65.27 & 5 & Nigeria & 462 & 114 \\
\hline Chile & 3.88 & 119 & Norway & 2.23 & 132 \\
\hline China, Republic & 4.62 & 115 & Oman & 6.80 & 99 \\
\hline Colombia & 4.67 & 113 & Pakistan & 13.56 & 62 \\
\hline Comoros & 65.19 & 6 & Panama & 4.56 & 116 \\
\hline Congo & 11.21 & 75 & Papua New Guinea & 12.28 & 69 \\
\hline Cote d'Ivoire & 11.22 & 74 & Paraguay & 14.13 & 58 \\
\hline Cyprus & 28.26 & 31 & Peru & 6.50 & 102 \\
\hline Denmark & 4.80 & 111 & Philippines & 8.61 & 89 \\
\hline Dominica & 12.93 & 67 & Portugal & 9.72 & 83 \\
\hline Dominican Republic & 21.23 & 40 & Saudi Arabia & 8.67 & 87 \\
\hline Ecuador & 5.82 & 105 & Senegal & 18.21 & 46 \\
\hline El Salvador & 10.04 & 80 & Seychelles & 168.21 & 1 \\
\hline Ethiopia & 41.43 & 19 & Sierra Leone & 13.57 & 61 \\
\hline Fiji & 17.25 & 52 & Singapore & 6.78 & 100 \\
\hline Finland & 4.14 & 118 & Spain & 5.40 & 107 \\
\hline France & 5.54 & 106 & Sri Lanka & 15.18 & 55 \\
\hline Gabon & 11.30 & 73 & St. Kitts and Nevis & 35.65 & 22 \\
\hline Gambia & 25.00 & 35 & St. Lucia & 20.26 & 42 \\
\hline Germany & 2.28 & 130 & St. Vincent & 16.46 & 54 \\
\hline Greece & 9.82 & 81 & Sudan & 19.72 & 43 \\
\hline Grenada & 34.84 & 24 & Surinam & 5.34 & 108 \\
\hline Guatemala & 13.16 & 64 & Swaziland & 2.14 & 134 \\
\hline Guinea & 12.98 & 66 & Sweden & 1.80 & 136 \\
\hline Guyana & 10.26 & 79 & Switzerland & 2.18 & 133 \\
\hline Haiti & 29.09 & 30 & Syrian Arab Republic & 13.87 & 60 \\
\hline Honduras & 8.65 & 88 & Tanzania & 40.37 & 20 \\
\hline Hungary & 4.43 & 117 & Thailand & 14.02 & 59 \\
\hline Iceland & 1.74 & 138 & Tonga & 124.74 & 2 \\
\hline India & 18.16 & 47 & Trinidad and Tobago & 8.10 & 91 \\
\hline Ireland & 3.60 & 124 & Tunisia & 7.68 & 95 \\
\hline Israel & 4.72 & 112 & United Kingdom & 2.49 & 129 \\
\hline Italy & 6.08 & 104 & United States & 3.72 & 122 \\
\hline Jamaica & 23.46 & 37 & Uruguay & 3.39 & 125 \\
\hline Japan & 3.16 & 126 & Vanuatu & 84.21 & 3 \\
\hline Jordan & 27.17 & 32 & Yemen Arab Republic & 46.88 & 14 \\
\hline Kenya & 30.44 & 28 & Yugoslavia & 8.34 & 90 \\
\hline Kiribai & 62.78 & 7 & Zimbabwe & 7.72 & 94 \\
\hline
\end{tabular}

Source: UNCTAD (1991), Table 5.1. The data pertain to 1987-89. 


\section{APPENDIX E \\ INDEX OF DISASTER PRONENESS*}

\begin{tabular}{|c|c|c|c|c|c|}
\hline Country & Index & Rank & Country & Index & Rank \\
\hline Afghanistan & 27.10 & 19 & Japan & 7.80 & 34 \\
\hline Algeria & 14.90 & 26 & Madagascar & 16.60 & 25 \\
\hline Antigua \& Barbuda & 38.00 & 14 & Malawi & 2.36 & 51 \\
\hline Argentina & 3.20 & 47 & Mali & 22.52 & 20 \\
\hline Australia & 4.08 & 44 & Mauritania & 41.15 & 12 \\
\hline Bangladesh & 38.00 & 15 & Mauritius & 40.68 & 13 \\
\hline Belize & 7.15 & 35 & Mexico & 2.91 & 48 \\
\hline Bolivia & 84.16 & 4 & Mozambique & 2.65 & 49 \\
\hline Botswana & 10.13 & 31 & Nepal & 16.84 & 24 \\
\hline Brazil & 3.21 & 46 & Niger & 21.53 & 23 \\
\hline Cape Verde & 12.06 & 30 & Pakistan & 5.54 & 40 \\
\hline Chad & 92.04 & 3 & Panama & 4.25 & 43 \\
\hline Chile & 5.90 & 37 & Paraguay & 5.08 & 41 \\
\hline China, Republic & 21.91 & 22 & Peru & 8.45 & 33 \\
\hline Colombia & 5.56 & 38 & Senegal & 21.98 & 21 \\
\hline Comoros & 61.18 & 8 & Spain & 1.99 & 53 \\
\hline Dominica & 141.30 & 2 & Sri Lanka & 3.40 & 45 \\
\hline Dominican Republic & 2.31 & 52 & St. Kitts and Nevis & 28.00 & 18 \\
\hline Ecuador & 2.52 & 50 & St. Lucia & 81.17 & 5 \\
\hline El Salvador & 52.32 & 10 & St. Vincent & 35.99 & 16 \\
\hline Ethiopia & 60.82 & 9 & Sudan & 5.56 & 39 \\
\hline Fiji & 14.68 & 27 & Swaziland & 12.60 & 29 \\
\hline Greece & 4.54 & 42 & Thailand & 1.27 & 55 \\
\hline Guatemala & 12.80 & 28 & Tonga & 50.20 & 11 \\
\hline Haiti & 9.21 & 32 & Tunisia & 1.37 & 54 \\
\hline Honduras & 34.82 & 17 & Uruguay & 1.01 & 56 \\
\hline Italy & 7.08 & 36 & Vanuatu & 228.41 & 1 \\
\hline Jamaica & 64.40 & 7 & Yemen Arab Republic & 66.67 & 6 \\
\hline
\end{tabular}

Source: UNDRO (1990).

*Only the countries that are disaster prone are included in the table. The index has been refined to exclude damage caused by civil strife. 
APPENDIX F

VULNERABILITY ADJUSTED DEVELOPMENT INDEX COMPARED TO GDP PER CAPITA

\begin{tabular}{|c|c|c|c|c|c|c|c|c|c|}
\hline Country & $\begin{array}{l}\text { VADI } \\
\text { Index* }\end{array}$ & Rank & $\begin{array}{l}\text { GDPPC } \\
\text { Index } \dagger\end{array}$ & Rank & Country & $\begin{array}{l}\text { VADI } \\
\text { Index* }\end{array}$ & Rank & $\begin{array}{l}\text { GDPPC } \\
\text { Index } \dagger\end{array}$ & Rank \\
\hline Afghanistan & 0.273 & 2 & 0.181 & 11 & Korea & 0.687 & 91 & 0.668 & 82 \\
\hline Algeria & 0.623 & 82 & 0.569 & 69 & Kuwait & 0.681 & 90 & 0.830 & 96 \\
\hline Antigua \& Barbuda & 0.394 & 21 & 0.631 & 78 & Liberia & 0.431 & 36 & 0.301 & 27 \\
\hline Argentina & 0.724 & 96 & 0.606 & 75 & Libya & 0.671 & 89 & 0.717 & 85 \\
\hline Australia & 0.786 & 102 & 0.893 & 100 & Madagascar & 0.345 & 15 & 0.118 & 6 \\
\hline Austria & 0.774 & 100 & 0.911 & 103 & Malawi & 0.281 & 4 & 0.095 & 4 \\
\hline Bahamas & 0.582 & 72 & 0.798 & 91 & Malaysia & 0.531 & 64 & 0.549 & 67 \\
\hline Bahrain & 0.587 & 75 & 0.761 & 90 & Maldives & 0.380 & 18 & 0.338 & 29 \\
\hline Bangladesh & 0.357 & 16 & 0.136 & 9 & Mali & 0.295 & 8 & 0.168 & 10 \\
\hline Barbados & 0.571 & 68 & 9,736 & 88 & Malta & 0.553 & 67 & 0.712 & 83 \\
\hline Belgium & 0.734 & 97 & 0.896 & 101 & Mauritania & 0.378 & 17 & 0.314 & 28 \\
\hline Belize & 0.452 & 41 & 0.515 & 61 & Mauritius & 0.459 & 45 & 0.532 & 65 \\
\hline Benin & 0.394 & 20 & 0.273 & 23 & Mexico & 0.648 & 85 & 0.551 & 68 \\
\hline Bolivia & 0.450 & 40 & 0.350 & 32 & Morocco & 0.512 & 59 & 0.412 & 68 \\
\hline Botswana & 0.489 & 51 & 0.513 & 60 & Mozambique & 0.305 & 11 & 0.000 & 1 \\
\hline Brazil & 0.734 & 98 & 0.579 & 71 & Nepal & 0.333 & 13 & 0.122 & 8 \\
\hline Cameroon & 0.542 & 66 & 0.448 & 49 & Netherlands & 0.724 & 95 & 0.897 & 102 \\
\hline Canada & 0.863 & 112 & 0.930 & 105 & New Zealand & 0.722 & 94 & 0.854 & 97 \\
\hline Cape Verde & 0.439 & 37 & 0.376 & 37 & Niger & 0.406 & 26 & 0.235 & 17 \\
\hline Chad & 0.217 & 1 & 0.120 & 7 & Nigeria & 0.454 & 43 & 0.217 & 13 \\
\hline Chile & 0.572 & 70 & 0.521 & 62 & Norway & 0.815 & 106 & 0.953 & 110 \\
\hline China, Republic & 0.472 & 49 & 0.244 & 19 & Oman & 0.651 & 86 & 0.718 & 86 \\
\hline Colombia & 0.585 & 73 & 0.461 & 51 & Pakistan & 0.419 & 31 & 0.232 & 16 \\
\hline Comoros & 0.334 & 14 & 0.270 & 22 & Panama & 0.520 & 62 & 0.542 & 66 \\
\hline Congo & 0.464 & 47 & 0.428 & 45 & Papua New Guinea & 0.466 & 48 & 0.420 & 44 \\
\hline Cote d'Ivoire & 0.481 & 50 & 0.403 & 40 & Paraguay & 0.522 & 63 & 0.501 & 58 \\
\hline Cyprus & 0.586 & 74 & 0.740 & 89 & Peru & 0.641 & 84 & 0.523 & 63 \\
\hline Denmark & 0.793 & 103 & 0.950 & 108 & Philippines & 0.493 & 55 & 0.354 & 33 \\
\hline Dominica & 0.455 & 44 & 0.510 & 59 & Portugal & 0.613 & 79 & 0.668 & 81 \\
\hline Dominican Republic & 0.423 & 32 & 0.359 & 34 & Saudi Arabia & 0.641 & 83 & 0.727 & 87 \\
\hline Ecuador & 0.540 & 65 & 0.430 & 46 & Senegal & 0.424 & 33 & 0.369 & 36 \\
\hline El Salvador & 0.504 & 58 & 0.440 & 47 & Seychelles & 0.443 & 39 & 0.643 & 80 \\
\hline Ethiopia & 0.279 & 3 & 0.063 & 2 & Sierra Leone & 0.406 & 27 & 0.217 & 14 \\
\hline $\mathrm{Fiji}$ & 0.459 & 46 & 0.491 & 57 & Singapore & 0.580 & 71 & 0.809 & 94 \\
\hline Finland & 0.823 & 107 & 0.953 & 109 & Spain & 0.748 & 99 & 0.802 & 94 \\
\hline France & 0.798 & 104 & 0.916 & 104 & Sri Lanka & 0.404 & 24 & 0.275 & 24 \\
\hline Gabon & 0.571 & 69 & 0.617 & 77 & St. Kitts and Nevis & 0.419 & 30 & 0.571 & 70 \\
\hline Gambia & 0.303 & 10 & 0.202 & 12 & St. Lucia & 0.408 & 29 & 0.531 & 64 \\
\hline Germany & 0.831 & 109 & 0.939 & 107 & St. Vincent & 0.408 & 28 & 0.464 & 52 \\
\hline Greece & 0.655 & 87 & 0.713 & 84 & Sudan & 0.515 & 60 & 0.293 & 26 \\
\hline Grenada & 0.426 & 34 & 0.487 & 55 & Surinam & 0.620 & 81 & 0.609 & 76 \\
\hline Guatemala & 0.499 & 56 & 0.408 & 41 & Swaziland & 0.453 & 42 & 0.393 & 39 \\
\hline Guinea Bissau & 0.295 & 7 & 0.110 & 5 & Sweden & 0.837 & 110 & 0.956 & 111 \\
\hline Guyana & 0.386 & 19 & 0.290 & 25 & Switzerland & 0.830 & 108 & 1.000 & 114 \\
\hline Haiti & 0.404 & 25 & 0.268 & 21 & Syrian Arab Republic & 0.594 & 76 & 0.469 & 53 \\
\hline Honduras & 0.492 & 52 & 0.412 & 42 & Tanzania & 0.284 & 5 & 0.066 & 3 \\
\hline Hungary & 0.611 & 77 & 0.593 & 73 & Thailand & 0.493 & 54 & 0.443 & 48 \\
\hline Iceland & 0.840 & 111 & 0.972 & 113 & Tonga & 0.317 & 12 & 0.393 & 38 \\
\hline India & 0.500 & 57 & 0.242 & 18 & Trinidad and Tobago & 0.612 & 78 & 0.640 & 79 \\
\hline Ireland & 0.688 & 92 & 0.804 & 93 & Tunisia & 0.515 & 61 & 0.470 & 54 \\
\hline lsrael & 0.714 & 93 & 0.812 & 95 & United Kingdom & 0.807 & 105 & 0.888 & 99 \\
\hline ltaly & 0.776 & 101 & 0.888 & 98 & United States & 0.890 & 113 & 0.939 & 106 \\
\hline Jamaica & 0.428 & 35 & 0.487 & 56 & Uruguay & 0.665 & 88 & 0.591 & 72 \\
\hline Japan & 0.895 & 114 & 0.968 & 112 & Vanuatu & 0.294 & 6 & 0.339 & 72 \\
\hline Jordan & 0.443 & 38 & 0.459 & 50 & Yemen Arab Republic & 0.403 & 23 & 0.345 & 31 \\
\hline Kenya & 0.394 & 22 & 0.258 & 20 & Yugoslavia & 0.616 & 80 & 0.595 & 74 \\
\hline Kiribati & 0.301 & 9 & 0.229 & 15 & Zimbabwe & 0.493 & 53 & 0.363 & 35 \\
\hline
\end{tabular}

*VADI (Vulnerability Adjusted Development Index) is computed on the basis of the following formula: [(1-VUL.INDEX) + GDP.INDEX)2]. †The GDP per capita index was standardized in the same manner as the Vulnerability Index. The highest rank refers to the highest GDP per capita. 


\section{APPENDIX G \\ COUNTRIES WITH AN OVERRATED GDP PER CAPITA*}

\begin{tabular}{lclclc}
\hline Country & Rank Diff. & Country & Rank Diff. & Country & Rank Diff. \\
\hline Antigua \& Barbuda & 57 & Malta & 16 & Kiribati & 6 \\
Seychelles & 41 & Dominica & 15 & Guyana & 6 \\
St. Kitts and Nevis & 40 & Cyprus & 15 & Chad & 6 \\
St. Lucia & 35 & Bahrain & 15 & Saudi Arabia & 4 \\
Tonga & 26 & Jordan & 12 & Panama & 4 \\
Vanuatu & 24 & Mauritania & 11 & Senegal & 3 \\
St. Vincent & 24 & Maldives & 11 & Malaysia & 3 \\
Singapore & 23 & Fiji & 11 & Benin & 3 \\
Jamaica & 21 & Botswana & 9 & Mali & 2 \\
Grenada & 21 & Afghanistan & 9 & Gambia & 2 \\
Mauritius & 20 & Yemen Arab Republic & 8 & Dominican Republic & 2 \\
Belize & 20 & Gabon & 8 & Trinidad and Tobago & 1 \\
Barbados & 20 & Comoros & 8 & & \\
Bahamas & 19 & Kuwait & 6 & & \\
\hline
\end{tabular}

*The figures show the difference between the GDP per capita rank and the VADI rank. Developing countries are classified as having an overrated GDP per capita if their GDP per capita rank higher than their VADI rank.

\section{APPENDIX $\mathrm{H}$ \\ COUNTRIES INCLUDED IN THE VULNERABILITY INDEX}

\begin{tabular}{|c|c|c|c|}
\hline Island developing countries & Non-island develop & ntries & Developed countries \\
\hline $\begin{array}{l}\text { Small Islands } \\
\text { Antigua and Barbuda } \\
\text { Bahamas } \\
\text { Bahrain } \\
\text { Barbados } \\
\text { Cape Verde } \\
\text { Comoros } \\
\text { Cyprus } \\
\text { Dominica } \\
\text { Fiji } \\
\text { Greneda } \\
\text { Kiribati } \\
\text { Maldives } \\
\text { Malta } \\
\text { Mauritius } \\
\text { Seychelles } \\
\text { St. Lucia } \\
\text { St. Kitts and Nevis } \\
\text { St. Vincent/Grenadines } \\
\text { Tonga } \\
\text { Trinidad and Tobago } \\
\text { Vanuatu } \\
\text { Large Islands } \\
\text { Dominican Republic } \\
\text { Haiti } \\
\text { Jamaica } \\
\text { Madagascar } \\
\text { Papua New Guinea } \\
\text { Phillipines } \\
\text { Singapore } \\
\text { Sri Lanka }\end{array}$ & $\begin{array}{l}\text { Afghanistan } \\
\text { Algeria } \\
\text { Argentina } \\
\text { Bangladesh } \\
\text { Belize } \\
\text { Benin } \\
\text { Bolivia } \\
\text { Botswana } \\
\text { Brazil } \\
\text { Cameroon } \\
\text { Chad } \\
\text { Chile } \\
\text { China } \\
\text { Colombia } \\
\text { Congo } \\
\text { Cote d'Ivoire } \\
\text { Ecuador } \\
\text { El Salvador } \\
\text { Ethiopia } \\
\text { Gabon } \\
\text { Gambia } \\
\text { Guatemala } \\
\text { Guinea-Bissau } \\
\text { Guyana } \\
\text { Honduras } \\
\text { Hungary } \\
\text { India } \\
\text { Israel } \\
\text { Jordan } \\
\text { Kenya } \\
\text { Korea, Republic of } \\
\text { Kuwait }\end{array}$ & $\begin{array}{l}\text { Liberia } \\
\text { Libya } \\
\text { Malawi } \\
\text { Malaysia } \\
\text { Mali } \\
\text { Mauritania } \\
\text { Mexico } \\
\text { Morocco } \\
\text { Mozambique } \\
\text { Nepal } \\
\text { Niger } \\
\text { Nigeria } \\
\text { Oman } \\
\text { Pakistan } \\
\text { Panama } \\
\text { Paraguay } \\
\text { Peru } \\
\text { Saudi Arabia } \\
\text { Senegal } \\
\text { Sierra Leone } \\
\text { Sudan } \\
\text { Suriname } \\
\text { Syrian Arab Rep. } \\
\text { Swaziland } \\
\text { Tanzania } \\
\text { Thailand } \\
\text { Tunisia } \\
\text { Uraguay } \\
\text { Yemen } \\
\text { Yugoslavia } \\
\text { Zimbabue }\end{array}$ & $\begin{array}{l}\text { Australia } \\
\text { Austria } \\
\text { Belgium } \\
\text { Canada } \\
\text { Denmark } \\
\text { Finland } \\
\text { France } \\
\text { Germany } \\
\text { Greece } \\
\text { Iceland } \\
\text { Ireland } \\
\text { Italy } \\
\text { Japan } \\
\text { Netherlands } \\
\text { New Zealand } \\
\text { Norway } \\
\text { Portugal } \\
\text { Spain } \\
\text { Sweden } \\
\text { Switzerland } \\
\text { United Kingdom } \\
\text { United States }\end{array}$ \\
\hline
\end{tabular}

